\section{Kepemimpinan Lurah Terhadap Pemberdayaan Masyarakat Di Kelurahan Lautang Benteng Kabupaten Sidenreng Rappang}

\author{
Ahmad Mustanir 1), Zainuddin \\ Samad 2), Abdul Jabbar 3), Monalisa \\ Ibrahim 4), Juniati 5) \\ 1 Program Studi Ilmu Pemerintahan, \\ Universitas Muhammadiyah Sidenreng \\ Rappang, Indonesia. \\ 2 Program Studi Administrasi Publik, \\ Universitas Muhammadiyah Sidenreng \\ Rappang, Indonesia. \\ ${ }^{3}$ Program Studi Ilmu Pemerintahan, \\ Universitas Muhammadiyah Sidenreng \\ Rappang, Indonesia. \\ ${ }^{4}$ Program Studi Administrasi Publik, \\ Universitas Muhammadiyah Sidenreng \\ Rappang, Indonesia. \\ ${ }^{5}$ Program Studi Ilmu Pemerintahan, \\ Universitas Muhammadiyah Sidenreng \\ Rappang, Indonesia.
}

*Korespondensi Penulis. E-mail: ahmadmustanir_74@umsrappang.ac.id1

\footnotetext{
Abstrak

Tujuan penelitian ini untuk mengetahui kepemimpinan lurah terhadap pemberdayaan masyarakat di Kelurahan Lautang Benteng Kecamatan Maritengngae Kabupaten Sidenreng Rappang. Tipe penelitian deskriptif kuantitatif. Sampel dalam penelitian yaitu 96 orang masyarakat dengan teknik purposive sampling menggunakan rumus Slovin. Pengumpulan data dilakukan melalui observasi dan kuesioner. Data yang ada dianalisis melalui tabel frekuensi menggunakan skala likert dan dilakukan metode analisis regresi linear sederhana melalui pengolahan SPSS 22.0. Hasilnya
}

memperlihatkan bahwa: Kepemimpinan Lurah sebesar $45,17 \%$ termasuk dalam kategori cukup baik; Pemberdayaan Masyarakat sebesar 39,6\% termasuk dalam kategori kurang baik; dan penelitian memperlihatkan kepemimpinan lurah berpengaruh terhadap pemberdayaan masyarakat. Ini dibuktikan melalui dengan perolehan output data dari tabel summary $\mathrm{R}^{2}$, kepemimpinan lurah memiliki pengaruh $13,3 \%$ terhadap pemberdayaan masyarakat sedangkan sisanya $86,7 \%$ dimungkinkan dipengaruhi oleh variabel lain diluar kerangka penelitian.

Kata kunci: Kepemimpinan, Partisipasi, Pemberdayaan Masyarakat

\section{LEADERSHIP OF THE LURAH IN EMPOWERMENT OF THE SOCIETY IN LAUTANG BENTENG, SIDENRENG RAPPANG REGENCY}

\begin{abstract}
The purpose of this study was to determine the leadership of the Lurah towards society empowerment in Lautang Benteng Village, Sidenreng Rappang Regency. Type of quantitative descriptive research. The sample in this study was 96 people with a purposive sampling technique using the Slovin formula. Data collection is done through observation and questionnaires. Existing data were analyzed through the frequency table using a Likert scale, and a simple linear regression analysis method was done through SPSS 22.0. The results show that: Lurah leadership of $45.17 \%$ is included in the quite good category; Society Empowerment by 39.6\% included in the group of not good, and research shows the Lurah leadership influences society empowerment. This is evidenced by the
\end{abstract}


acquisition of output data from summary table R2, Lurah leadership has a 13.3\% influence on society empowerment while the remaining $86.7 \%$ is likely to be influenced by other variables outside the research framework.

Keywords: Leadership, Participation, Society Empowerment

\section{A. PENDAHULUAN}

Di lingkup kelurahan harus terjadi pembangunan dan perubahan ke arah yang lebih baik. Hal tersebut dapat diwujudkan oleh Kepala Kelurahan secara terencana dan dapat dilakukan dengan adanya pemberdayaan masyarakat. Pemberdayaan masyarakat dapat dilakukan melalui partisipasi aktif masyarakat yang harus difasilitasi dengan adanya pelaku pemberdayaan masyarakat yang berasal dari seorang pemimpin. Jika kondisi seorang pemimpin sejalan dengan masyarakat maka dengan sukarela masyarakat akan ikut berperan aktif terhadap proses pembangunan. Partisipasi masyarakat sangat dibutuhkan untuk membantu kegiatan seperti peningkatan mutu dan pembangunan di daerah, sesuai dengan kemampuan masing-masing. Kesediaan masyarakat untuk mengambil bagian dari penyelenggaraan suatu program pembangunan adalah merupakan indikasi adanya kemampuan awal dari masyarakat untuk menumbuhkan keberdayaan diri masyarakat dan berkembang secara mandiri.
Sejalan dengan yang dikemukakan oleh Kartono (2014) bahwa kepemimpinan memiliki fungsi sebagai penggerak atau dinamisator dan koordinator dari sumber daya manusia, sumber daya alam, semua dana serta sarana yang disiapkan oleh sekumpulan manusia yang berorganisasi. Dalam konteks memberdayakan masyarakat, seorang Lurah sebagai pemimpin harus berperan dalam memberikan pemahaman kepada masyarakat tentang bagaimana upaya-upaya teknis, praktis, dan operasional dalam mengembangkan kemampuan diri dalam masyarakatnya dan menyukseskan urusan dan kepentingan yang dikelolanya. Tidak hanya sampai pemberian pemahaman, pemimpin perlu untuk secara terus-menerus melakukan pembinaan kepada masyarakatnya, agar masyarakat memahami dan selalu termotivasi untuk membangun dirinya sendiri secara mandiri. Dalam memudahkan segala kegiatan tersebut maka seorang pemimpin juga harus memfasilitasi segala kegiatan tersebut.

Di Kelurahan Lautang Benteng Kecamatan Maritengngae, Kepala Kelurahan belum dapat menyelenggarakan kegiatan pemberdayaan masyarakat. Hal itu dapat diidentifikasi dari tugas pokok atau fungsi seorang Kepala Kelurahan. Adapun tugas utama dari seorang Lurah yang disampaikan oleh Sekretaris Kelurahan Lautang Benteng berkaitan dengan pemberdayaan masyarakat ialah; (a) 
pembentukan lembaga-lembaga

pemberdayaan masyarakat; (b) pelaksanaan kegiatan yang telah disusun dengan lembaga-lembaga pemberdayaan yang terkait; (b) penyediaan sarana prasarana; (c) pengawasan kegiatan pemberdayaan masyarakat; dan (c) mengevaluasi atau menilai hasil (output) dari kegiatan tersebut.

Berdasarkan data di Kelurahan Lautang Benteng terdapat tiga lembaga yang dapat melaksanakan pemberdayaan masyarakat atau menjadi mitra kegiatan pemberdayaan masyarakat yaitu Lembaga Pemberdayaan Masyarakat (LPM), Pembinaan Kesejahteraan Keluarga (PKK), dan Badan Keswadayaan Masyarakat (BKM). Lembaga-lembaga tersebut telah lama dibentuk namun sampai saat ini belum ada program atau kegiatan pemberdayaan masyarakat yang dilaksanakan. Justru yang dilihat jelas oleh masyarakat pelaksanaan kegiatan pemberdayaan masyarakat dilakukan oleh lembaga eksternal.

Di Kelurahan Lautang Benteng terdapat lembaga eksternal atau mitra kegiatan pemberdayaan masyarakat seperti Lembaga Kursus dan Pelatihan (LKP), Pusat Kegiatan Belajar Masyarakat (PKBM), dan yayasan pelatihan sesuai dengan kompetensi masyarakat. Lembagalembaga tersebut tidak memiliki keterkaitan dengan pemberdayaan yang terbentuk dari pemerintah kelurahan, bahkan dana dan fasilitasnya berasal dari pemerintah pusat. Lembaga-lembaga tersebut, yaitu a) LKP Anda (Jalan Anoa); b) LKP Anhysa (Jalan Rusa); c) Yayasan Ifah (Jalan Domba); d) PKBM Dyna (Jalan Domba); e) LKP Adhydah (Jalan Landaung); f) PKBM Buana Rias (Jalan Banteng)

Kini sebagian masyarakat di Kelurahan Lautang Benteng dapat mengembangkan kemampuan yang dimiliki atau mengikuti apa yang menjadi minat mereka seperti kegiatan menjahit, tata boga, atau tata rias melalui lembaga tersebut. Bahkan untuk bergabung di lembaga tersebut tidak dipungut biaya apapun (gratis) dan diberikan alat atau perlengkapan sesuai dengan kebutuhan mereka. Di sisi lain, ada pula masyarakat yang mengeluh dengan lembaga-lembaga tersebut yang tidak dapat mengikutsertakan mereka semua karena adanya persyaratan tertentu, seperti batas jumlah peserta dan batasan usia.

Masyarakat yang telah mengetahui dan memahami jika di kelurahan mereka terdapat lembaga yang dapat melaksanakan kegiatan pemberdayaan masyarakat seperti LPM, PKK, atau BKM sangat menyayangkan lembaga tersebut karena tidak menjalankan fungsi sebagaimana mestinya dan menganggap bahwa lembaga tersebut dibentuk hanya sebagai pelengkap di kelurahan mereka. Masyarakat menginginkan lembaga-lembaga tersebut dapat mengikutsertakan semua masyarakat yang ingin mengembangkan kemampuan di bidang tertentu sesuai dengan minat masing-masing (seperti menjahit, tata boga, tata rias, ataupun di bidang 
otomotif). Mereka juga menginginkan Lurah bertindak tegas terhadap bawahannya dan selalu memotivasi masyarakat untuk bergerak ke arah perubahan yang lebih baik demi peningkatan ekonomi dan taraf kehidupan yang lebih baik.

\section{B. TEORI (Literature Review) 1. Kepemimpinan Pemerintahan}

Suradji dan Martono dalam Sriekaningsih (2017) (Latif, Mustanir, \& Irwan, 2019) (Mustanir, Madaling, et al., 2019) (Damis Dadda, Mustanir, Nilwana, \& Ahmad, 2019) (Mustanir \& Jaya, 2016) (Irwan, Latif, Sofyan, Mustanir, \& Fatimah, 2019), mengemukakan kepemimpinan adalah proses dalam mempengaruhi orang agar dapat memahami dan menyetujui dengan hal yang diinginkan serta berupaya untuk memfasilitasi agar dapat tercapai suatu tujuan bersama.

Dalam menjalankan kepemimpinannya dan mencapai tujuan yang diinginkan, maka seorang pemimpin harus memiliki teknik kepemimpinan, karena dengan teknik kepemimpinan itulah yang akan menunjukan bahwa ia mampu untuk memimpin dan merupakan pencerminan jati dirinya sebagai seorang pemimpin. Syafiie (2014), teknik merupakan cara atau strategi yang dilakukan seseorang untuk mencapai tujuannya. Dalam hal ini pemimpin harus memiliki berbagai teknik dalam memengaruhi para bawahan atau masyarakatnya agar tujuan yang diharapkan segera tercapai sesuai dengan kemampuan pemimpin pemerintahan itu sendiri.

Berikut ini disampaikan oleh Syafiie (2013) beberapa teknik dalam kepemimpinan pemerintahan yaitu a) teknik persuasif adalah strategi pemimpin pemerintahan untuk memotivasi bawahannya agar lebih rajin dalam bekerja. Ini dilakukan secara lemah lembut. Teknik ini yaitu pemimpin pemerintahan melakukan pendekatan dengan bujukan di mana untuk memotivasi bawahan atau masyarakat dipergunakan strategi pemanjaan. Dengan demikian bawahan atau masyarakat akan melaksanakan pekerjaan karena alasan baik hatinya atasan (sang pemimpin). Disimpulkan bahwa teknik persuasif ini seorang pemimpin akan memengaruhi bawahan atau masyarakatnya dengan membujuk mereka secara halus. Jika bujukan tersebut berhasil, maka mereka akan mengikuti atau bertingkah lakuseperti yang dikehendaki oleh sang pemimpin; b) teknik komunikatif dimana teknik ini pemimpin menerapkan strategi untuk mencapai tujuan melalui komunikasi yang baik dengan masyarakat. Pemimpin pemerintahan harus memiliki media komunikasi yang baik dan benar, antara lain berbahasa dengan baik dan benar, menuliskan pesan dengan jelas, mempergunakan pengeras suara yang memadai, berada pada tempat yang resmi, ciptakan situasi di mana bawahan dan masyarakat serius.

Menurut Pamudji dalam Syarifudin (2013) komunikasi berarti 
penyampaian suatu maksud kepada pihak lain dalam rangka penerangan, persuasi ataupun perintah dan yang terpenting maksud tersebut diterima sama dengan maksud sang pengirim. Seringkali terjadi bahwa maksud tersebut diterima dan ditafsirkan lain.

Disimpulkan bahwa teknik komunikatif ialah kegiatan yang dilakukan pemimpin untuk mengarahkan segala aktifitas organisasi dengan berkomunikasi secara baik dengan bawahan atau masyarakatnya. Komunikasi terbaik adalah komunikasi dua arah yaitu komunikasi timbal balik antara pemimpin dengan bawahan atau masyarakat. Dengan demikian, maksud yang disampaikan dalam komunikasi tersebut mudah diterima dan dipahami.

Teknik fasilitas dimana teknik ini pemimpin memilih strategi dengan memberikan fasilitas kepada masyarakat dan mereka terikat atas hal tersebut. Hal ini disebut dengan kekuatan pemberian (reward power). Pamudji dalam Syarifudin (2013) mengemukakan bahwa apabila sekelompok orang telah bersedia dan merasa siap untuk mengikuti ajakan pemimpin, maka orang-orang tersebut harus diberikan fasilitasfasilitas yang meliputi kecakapan yang diberikan melalui latihan, uang, perlengkapan, tempat kerja, serta perangsang (materi ataupun non materi). Disimpulkan bahwa teknik fasilitas adalah kegiatan yang dilakukan pemimpin dalam memengaruhi bawahan atau masyarakatnya dengan cara memfasilitasi seluruh kegiatan organisasi dan menyediakan fasilitas umum sesuai dengan yang diperlukan oleh masyarakatnya.

Teknik motivasi dalam kepemimpinan pemerintahan ialah strategi pemimpin untuk mendorong bawahan atau masyarakatnya bekerja serta membangun lebih rajin dengan berbagai cara.

Sedangkan menurut Pamudji dalam Syarifudin (2013) teknik motivasi sama dengan teknik hubungan antara manusia (human relation) yang berarti suatu proses atau rangkaian kegiatan untuk memotivasi orang-orang, yakni keseluruhan proses memberikan motivasi (dorongan) agar orangorang tersebut mau bergerak mengikuti pemimpin yang diharapkan dapat memenuhi kebutuhan masyarakat(Mustanir, Ramadhan, et al., 2019) (Mustanir, Madaling, et al., 2019).

Berdasarkan uraian di atas, dapat disimpulkan bahwa teknik motivasi adalah cara yang dilakukan pemimpin untuk memengaruhi bawahan atau masyarakatnya ke arah yang ia kehendaki dengan memberikan dorongan dan semangat hidup. Hal itu akan memengaruhi sikap dan tingkah laku mereka untuk berpikir dan bertindak sesuai dengan yang dikehendaki. Motivasi pada umumnya tidak terlepas dari bagaimana pemenuhan kebutuhankebutuhan bawahan atau masyarakat.

Teknik keteladanan dalam kepemimpinan pemerintahan merupakan strategi pemimpin pemerintahan dalam memberikan contoh yang baik kepada bawahan maupun masyarakatnya sendiri. 
Adapun menurut Pamudji dalam Syarifudin (2013) teknik menjadi teladan diharapkan dapat memberikan contoh-contoh kepada orang-orang yang harus digerakkan agar mereka mengikuti apa yang mereka telah lihat. Pemimpin yang baik akan menunjukkan bahwa ia mampu untuk memimpin dan merupakan pencerminan jati dirinya sebagai seorang pemimpin dengan melakukan teknik-teknik untuk pencapaian organisasinya.

Berdasarkan uraian di atas, dapat disimpulkan bahwa teknik keteladanan merupakan salah satu cara yang dilakukan oleh pemimpin dalam menggerakkan dan memengaruhi bawahan atau masyarakatnya. Pemimpin harus selalu memberikan contoh yang baik dalam setiap kegiatan yang dilaksanakan, misalnya tekun, disiplin, tidak melanggar aturan, dan lain sebagainya. Seorang pemimpin harus berusaha menjadikan dirinya panutan atau teladan yang baik, sehingga bawahan atau masyarakatnya akan mengikuti keteladanan tersebut.

\section{Pemberdayaan Masyarakat}

Proses pemberdayaan masyarakat akan merujuk pada suatu tindakan nyata yang dilakukan secara bertahap untuk melakukan perubahan atau mengubah kondisi masyarakat. Terkait hal ini, (Mustanir, Hamid, \& Syarifuddin, 2019) (Uceng, Ali, Mustanir, \& Nirmawati, 2019) (Mustanir \& Darmiah, 2016) (Mustanir \& Lubis, 2017) (Mustanir \& Abadi, 2017) Sumadyo dalam Mardikanto dan Soebiato (2017) menyebutkan 3 bina dalam pemberdayaan masyarakat yang dikenal dengan Tri Bina, yaitu bina manusia, bina usaha, dan bina lingkungan.

Mardikanto menambahkan akan pentingnya suatu kelembagaan, karena proses pemberdayaan masyarakat pada hakikatnya adalah proses pengembangan kapasitas, yaitu: pengembangan kapasitas manusia (bina manusia), kapasitas usaha (bina usaha), kapasitas lingkungan (bina lingkungan), dan kapasitas kelembagaan (bina kelembagaan).

Pengembangan kapasitas manusia (bina manusia) adalah upaya yang pertama dan paling utama untuk diperhatikan dalam setiap upaya pemberdayaan masyarakat. Termasuk dalam bina ini adalah upaya pengembangan kapasitas. Disimpulkan bahwa bina manusia ialah salah satu upaya dalam pemberdayaan masyarakat yaitu dengan peningkatan kualitas Sumber Daya Manusia (SDM). Upaya yang dilakukan untuk mengembangkan kemampuan individu adalah dengan melaksanakan berbagai program pembinaan atau pelatihan sesuai dengan potensi individu.

Pengembangan kapasitas usaha (bina usaha) adalah proses pemberdayaan, karena pengembangan kapasitas manusia yang tanpa memberikan dampak atau manfaat bagi perbaikan kesejahteraan (ekonomi dan atau ekonomi) tidak akan berhasil. Sebaliknya, hanya pembinaan usaha yang mampu (dalam waktu dekat atau cepat) memberikan dampak atau manfaat bagi perbaikan 
kesejahteraan (ekonomi dan atau ekonomi) yang akan laku atau memperoleh dukungan dalam bentuk partisipasi masyarakat.

Berdasarkan uraian di atas, dapat disimpulkan bahwa bina usaha merupakan suatu upaya yang dilakukan untuk memperbaiki kesejahteraan hidup masyarakat. Dalam perbaikan usaha perlu dilakukan pendampingan kepada pelaku usaha (masyarakat), pembentukan badan usaha hingga memberikan fasilitas untuk usahausaha yang dijalankan masyarakat.

$$
\text { Pengembangan kapasitas }
$$

lingkungan (bina lingkungan) sangat diperlukan karena bina usaha yang tidak terkendali dapat menjurus pada ketamakan atau kerakusan yang dapat merusak lingkungan (baik lingkungan fisik maupun lingkungan sosial). Hal ini dinilai penting, karena pelestarian lingkungan (fisik) akan sangat menentukan keberlanjutan kegiatan investasi ataupun operasi (utamanya yang terkait dengan tersedianya bahan baku) (Kholifah R \& Mustanir, 2019).

Selama ini pengertian lingkungan seringkali dimaknai hanya sekedar lingkungan fisik, utamanya yang menyangkut pelestarian sumber daya alam dan lingkungan hidup. Tetapi dalam praktiknya perlu disadari bahwa lingkungan sosial juga sangat berpengaruh terhadap keberlanjutan bisnis dan kehidupan. Termasuk dalam tanggungjawab sosial merupakan segala kewajiban yang harus dilakukan yang terkait dengan upaya perbaikan kesejahteraan sosial masyarakat yang tinggal di dalam dan di sekitar kawasan (areal kerja), maupun yang mengalami dampak negatif yang diakibatkan oleh kegiatan yang dilakukan oleh penanaman modal atau perseroan.

$$
\text { Adapun yang termasuk }
$$
tanggungjawab lingkungan adalah kewajiban dipenuhinya segala kewajiban yang ditetapkan dalam persyaratan investasi dan operasi yang terkait dengan perlindungan, pelestarian, dan pemulihan (rehabilitasi atau reklamasi) sumber daya alam dan lingkungan hidup.

Berdasarkan uraian di atas, dapat disimpulkan bahwa bina lingkungan memiliki hubungan yang erat dengan bina usaha. Jika dalam kegiatan bina usaha lingkungan tidak diperhatikan sebaik mungkin maka akan merusak lingkungan itu sendiri. Maka dari itu, pelestarian sumber daya alam dan perbaikan lingkungan hidup sangat menentukan keberlanjutan kegiatan investasi atau operasi (tersedianya bahan baku).

Pengertian tentang kelembagaan seringkali dimaknai dalam arti sempit sebagai beragam bentuk lembaga (kelompok ataupun organisasi). Tetapi kelembagaan sebenarnya memiliki arti yang lebih luas. Hayami dan Kikuchi dalam Mardikanto dan Soebiato (2017) mengartikan kelembagaan sebagai suatu perangkat umum yang ditaati oleh anggota suatu komunitas atau masyarakat. Dalam kehidupan seharihari, kelembagaan yang merupakan terjemahan dari kata "institution" adalah suatu konsep yang tergolong membingungkan dan dapat dikatakan belum memperoleh pengertian yang mantap dalam ilmu sosiologi (Sellang, 
Kamaruddin; Ahmad, Jamaluddin; Mustanir, 2019).

Dapat disimpulkan bahwa bina kelembagaan merupakan pembentukan atau perbaikan suatu kelompok atau lembaga pemberdayaan masyarakat. Unsur penting yang harus diperbaiki dalam suatu lembaga di antaranya: individu yang terlibat di dalamnya; tujuan lembaga; aturan lembaga; dan struktur lembaga tersebut.

\section{METODE}

Metode penelitian menggunakan jenis penelitian deskriptif kuantitatif dengan tetap melakukan wawancara pada informan sebagai penegasan hasil yang diperoleh. Populasi adalah Kepala Keluarga (KK) di Kelurahan Lautang Benteng Kecamatan Maritengngae Kabupaten Sidenreng Rappang yang berjumlah 2.366 KK. Sampel sebanyak 96. Pengumpulan data dilakukan dengan observasi dan kuesioner. Dalam menganalisis data digunakan analisis regresi linier sederhana dengan SPSS 22.0. Hasil analisisnya berupa analisis tabel frekuensi menggunakan skala likert (Ahmad, 2015; Sugiyono, 2014). Kualitas data dilakukan dengan uji validitas dan uji reliabilitas. Uji validitas adalah ukuran yang menunjukkan tingkat kevalidan atau keabsahan suatu instrumen. Instrumen dikatakan valid apabila dapat mengungkapkan data dari variabel yang diteliti. Model pengujian menggunakan pendekatan korelasi item-total dikoreksi (correction item-total correlation) untuk menguji validitas internal setiap item pernyataan kuesioner yang disusun dalam bentuk skala. Dinyatakan valid atau tidak maka para ahli menetapkan patokan besaran koefisien korelasi item-total dikoreksi sebesar 0,25 atau 0,30 sebagai batas minimal valid tidaknya sebuah item. Artinya sama atau lebih besar dari 0,25 atau 0,30 mengindikasikan item tersebut memiliki validitas yang memadai. Uji reliabilitas jika jawaban seseorang terhadap pertanyaan adalah konsisten atau stabil dari waktu ke waktu atau variabel dikatakan reliabel jika memberikan nilai Cronbach Alpha $\leq 0,60$. Koefisien determinasi untuk mengukur seberapa jauh kemampuan model dalam menerangkan variasi variabel dependen. Nilai koefisien determinasi antara nol dan satu. Nilai $\mathrm{R}^{2}$ yang kecil berarti kemampuan variabel independen dalam menjelaskan variasi variabel dependen amat terbatas. Nilai yang mendekati satu berarti variabel independen memberikan hampir semua informasi yang dibutuhkan untuk memprediksi variabel dependen. Namun, besar kecilnya $\mathrm{R}^{2}$ tidak dapat dijadikan alasan bahwa model tersebut "baik", sebab besar kecilnya nilai $\mathrm{R}^{2}$ bergantung pada jumlah variabel independen yang digunakan. Semakin banyak variabel independen maka $r^{2}$ semakin besar. 


\section{HASIL DAN PEMBAHASAN}

\section{1) Kepemimpinan lurah}

Dari variabel kepemimpinan diperoleh indikator hasil sesuai tabeltabel berikut.

Tabel 1. Tanggapan responden tentang ajakan dari Lurah kepada masyarakat untuk memengaruhi mereka agar ikut serta dalam suatu kegiatan

\begin{tabular}{|c|c|c|c|c|}
\hline $\begin{array}{c}\text { Alternatif } \\
\text { Jawaban }\end{array}$ & Bobot & Frekuensi & Skor & $\begin{array}{c}\text { Persentase } \\
(\%)\end{array}$ \\
\hline $\begin{array}{c}\text { Sangat } \\
\text { baik }\end{array}$ & 5 & 0 & 0 & $0 \%$ \\
\hline Baik & 4 & 4 & 16 & $4,2 \%$ \\
\hline $\begin{array}{c}\text { Cukup } \\
\text { baik }\end{array}$ & 3 & 39 & 117 & $40,6 \%$ \\
\hline $\begin{array}{c}\text { Kurang } \\
\text { baik }\end{array}$ & 2 & 37 & 74 & $38,5 \%$ \\
\hline Tidak baik & 1 & 16 & 16 & $16,7 \%$ \\
\hline \multicolumn{2}{|c|}{ Jumlah } & 96 & 223 & $100 \%$ \\
\hline \multicolumn{2}{|c|}{ Rata-rata skor } & \multicolumn{3}{|c|}{$223 / 96=2,32$} \\
\hline $\begin{array}{c}\text { Rata-rata } \\
\text { persentase }\end{array}$ & $2,32 / 5 \times 100 \%=46,4 \%$ \\
\hline
\end{tabular}

Sumber: Hasil Olah Data Kuesioner (Mei 2019)

Tabel 2. Tanggapan responden tentang komunikasi yang terjalin antara Lurah dengan masyarakat

\begin{tabular}{|c|c|c|c|c|}
\hline $\begin{array}{c}\text { Alternatif } \\
\text { Jawaban }\end{array}$ & Bobot & Frekuensi & Skor & $\begin{array}{c}\text { Persentase } \\
(\%)\end{array}$ \\
\hline $\begin{array}{c}\text { Sangat } \\
\text { baik }\end{array}$ & 5 & 0 & 0 & $0 \%$ \\
\hline Baik & 4 & 4 & 16 & $4,2 \%$ \\
\hline $\begin{array}{c}\text { Cukup } \\
\text { baik }\end{array}$ & 3 & 32 & 96 & $33,3 \%$ \\
\hline $\begin{array}{c}\text { Kurang } \\
\text { baik }\end{array}$ & 2 & 53 & 106 & $55,2 \%$ \\
\hline Tidak baik & 1 & 7 & 7 & $7,3 \%$ \\
\hline \multicolumn{2}{|c|}{ Jumlah } & 96 & 225 & $100 \%$ \\
\hline \multicolumn{2}{|c|}{ Rata-rata skor } & \multicolumn{3}{c|}{$225 / 96=2,34$} \\
\hline \multicolumn{2}{|c|}{$\begin{array}{c}\text { Rata-rata } \\
\text { persentase }\end{array}$} & $2,34 / 5 \times 100 \%=46,8 \%$ \\
\hline
\end{tabular}

Sumber: Hasil Olah Data Kuesioner (Mei 2019)
Tabel 3 Tanggapan responden tentang kejelasan informasi yang diberikan oleh

Lurah kepada masyarakat

\begin{tabular}{|c|c|c|c|c|}
\hline $\begin{array}{c}\text { Alternatif } \\
\text { Jawaban }\end{array}$ & Bobot & Frekuensi & Skor & $\begin{array}{c}\text { Persentase } \\
(\%)\end{array}$ \\
\hline $\begin{array}{c}\text { Sangat } \\
\text { jelas }\end{array}$ & 5 & 0 & 0 & $0 \%$ \\
\hline Jelas & 4 & 6 & 24 & $6,2 \%$ \\
\hline $\begin{array}{c}\text { Cukup } \\
\text { jelas }\end{array}$ & 3 & 32 & 96 & $33,3 \%$ \\
\hline $\begin{array}{c}\text { Kurang } \\
\text { jelas }\end{array}$ & 2 & 41 & 82 & $42,7 \%$ \\
\hline $\begin{array}{c}\text { Tidak } \\
\text { jelas }\end{array}$ & 1 & 17 & 17 & $17,7 \%$ \\
\hline \multicolumn{2}{|c|}{ Jumlah } & 96 & 219 & $100 \%$ \\
\hline \multicolumn{2}{|c|}{ Rata-rata skor } & \multicolumn{3}{|c|}{$219 / 96=2,28$} \\
\hline \multicolumn{2}{|c|}{ Rata-rata } \\
persentase
\end{tabular}

Sumber: Hasil Olah Data Kuesioner (Mei 2019)

Tabel 4 Tanggapan responden tentang kesesuaian antara fasilitas yang disediakan oleh Lurah dengan apa yang menjadi kebutuhan masyarakat

\begin{tabular}{|c|c|c|c|c|}
\hline $\begin{array}{c}\text { Alternatif } \\
\text { Jawaban }\end{array}$ & Bobot & Frekuensi & Skor & $\begin{array}{c}\text { Persentase } \\
(\%)\end{array}$ \\
\hline $\begin{array}{c}\text { Sangat } \\
\text { sesuai }\end{array}$ & 5 & 0 & 0 & $0 \%$ \\
\hline Sesuai & 4 & 6 & 24 & $6,2 \%$ \\
\hline $\begin{array}{c}\text { Cukup } \\
\text { sesuai }\end{array}$ & 3 & 33 & 99 & $34,4 \%$ \\
\hline $\begin{array}{c}\text { Kurang } \\
\text { sesuai }\end{array}$ & 2 & 36 & 72 & $37,5 \%$ \\
\hline $\begin{array}{c}\text { Tidak } \\
\text { sesuai }\end{array}$ & 1 & 21 & 21 & $21,9 \%$ \\
\hline \multicolumn{2}{|c|}{ Jumlah } & 96 & 216 & $100 \%$ \\
\hline \multicolumn{2}{|c|}{ Rata-rata skor } & \multicolumn{3}{|c|}{$216 / 96=2,25$} \\
\hline $\begin{array}{c}\text { Rata-rata } \\
\text { persentase }\end{array}$ & \multicolumn{2}{c|}{$25 / 5 \times 100 \%=45 \%$} \\
\hline
\end{tabular}

Sumber: Hasil Olah Data Kuesioner (Mei 2019) 
Tabel 5 Tanggapan responden tentang pemberian motivasi atau dukungan dari Lurah kepada masyarakat

\begin{tabular}{|c|c|c|c|c|}
\hline $\begin{array}{c}\text { Alternatif } \\
\text { Jawaban }\end{array}$ & Bobot & Frekuensi & Skor & $\begin{array}{c}\text { Persentase } \\
(\%)\end{array}$ \\
\hline $\begin{array}{c}\text { Sangat } \\
\text { baik }\end{array}$ & 5 & 0 & 0 & $0 \%$ \\
\hline Baik & 4 & 7 & 28 & $7,3 \%$ \\
\hline $\begin{array}{c}\text { Cukup } \\
\text { baik }\end{array}$ & 3 & 28 & 84 & $29,1 \%$ \\
\hline $\begin{array}{c}\text { Kurang } \\
\text { baik }\end{array}$ & 2 & 47 & 94 & $49 \%$ \\
\hline Tidak baik & 1 & 14 & 14 & $14,6 \%$ \\
\hline \multicolumn{2}{|c|}{ Jumlah } & 96 & 220 & $100 \%$ \\
\hline \multicolumn{2}{|c|}{ Rata-rata skor } & \multicolumn{3}{|c|}{$220 / 96=2,29$} \\
\hline \multicolumn{2}{|c|}{$\begin{array}{c}\text { Rata-rata } \\
\text { persentase }\end{array}$} & $2,29 / 5 \times 100 \%=45,8 \%$ \\
\hline
\end{tabular}

Sumber: Hasil Olah Data Kuesioner (Mei 2019)

Tabel 6 Tanggapan responden tentang motivasi atau dukungan yang diberikan oleh Lurah kepada masyarakat mampu atau tidak dalam memacu semangat mereka untuk bergerak ke arah perubahan yang lebih baik

\begin{tabular}{|c|c|c|c|c|}
\hline $\begin{array}{c}\text { Alternatif } \\
\text { Jawaban }\end{array}$ & Bobot & Frekuensi & Skor & $\begin{array}{c}\text { Persentase } \\
(\%)\end{array}$ \\
\hline $\begin{array}{c}\text { Sangat } \\
\text { mampu }\end{array}$ & 5 & 0 & 0 & $0 \%$ \\
\hline Mampu & 4 & 6 & 24 & $6,2 \%$ \\
\hline $\begin{array}{c}\text { Cukup } \\
\text { mampu }\end{array}$ & 3 & 22 & 66 & $22,9 \%$ \\
\hline $\begin{array}{c}\text { Kurang } \\
\text { mampu }\end{array}$ & 2 & 54 & 108 & $56,2 \%$ \\
\hline $\begin{array}{c}\text { Tidak } \\
\text { mampu }\end{array}$ & 1 & 14 & 14 & $14,6 \%$ \\
\hline \multicolumn{2}{|c|}{ Jumlah } & 96 & 212 & $100 \%$ \\
\hline \multicolumn{2}{|c|}{ Rata-rata skor } & \multicolumn{3}{|c|}{$212 / 96=2,20$} \\
\hline $\begin{array}{c}\text { Rata-rata } \\
\text { persentase }\end{array}$ & \multicolumn{4}{c}{$20 / 5 \times 100 \%=44 \%$} \\
\hline
\end{tabular}

Sumber: Hasil Olah Data Kuesioner (Mei 2019)
Tabel 7 Tanggapan responden tentang kemampuan Lurah untuk menjadi contoh (suri tauladan) yang baik bagi masyarakat

\begin{tabular}{|c|c|c|c|c|}
\hline $\begin{array}{c}\text { Alternatif } \\
\text { Jawaban }\end{array}$ & Bobot & Frekuensi & Skor & $\begin{array}{c}\text { Persentase } \\
(\%)\end{array}$ \\
\hline $\begin{array}{c}\text { Sangat } \\
\text { mampu }\end{array}$ & 5 & 0 & 0 & $0 \%$ \\
\hline Mampu & 4 & 6 & 24 & $6,2 \%$ \\
\hline $\begin{array}{c}\text { Cukup } \\
\text { mampu }\end{array}$ & 3 & 20 & 60 & $20,8 \%$ \\
\hline $\begin{array}{c}\text { Kurang } \\
\text { mampu }\end{array}$ & 2 & 51 & 102 & $53,1 \%$ \\
\hline $\begin{array}{c}\text { Tidak } \\
\text { mampu }\end{array}$ & 1 & 19 & 19 & $19,8 \%$ \\
\hline \multicolumn{2}{|c|}{ Jumlah } & 96 & 205 & $100 \%$ \\
\hline $\begin{array}{c}\text { Rata-rata skor } \\
\text { Rata-rata } \\
\text { persentase }\end{array}$ & \multicolumn{3}{|c|}{$205 / 96=2,13 / 5 \times 100 \%=42,6 \%$} \\
\hline
\end{tabular}

Sumber: Hasil Olah Data Kuesioner (Mei 2019)

Dari hasil yang diperoleh dalam tabel-tabel indikator dari variabel kepemimpinan diatas maka rekapitulasi variabel kepemimpinan lurah dapat dilihat pada Tabel 8 . 
Tabel 8. Rekapitulasi Variabel

Kepemimpinan Lurah (X)

\begin{tabular}{|c|c|c|}
\hline Indikator & Tanggapan Responden & $\begin{array}{c}\text { Persentase } \\
(\%)\end{array}$ \\
\hline $\begin{array}{c}\text { Teknik } \\
\text { persuasif }\end{array}$ & \begin{tabular}{lr} 
Pemberian & bujukan \\
dari Lurah & kepada \\
masyarakat untuk & memengaruhi mereka \\
mem & \multicolumn{2}{l}{ agar ikut serta dalam } \\
\multicolumn{2}{c}{ suatu kegiatan. }
\end{tabular} & $46,4 \%$ \\
\hline $\begin{array}{c}\text { Teknik } \\
\text { komunikatif }\end{array}$ & 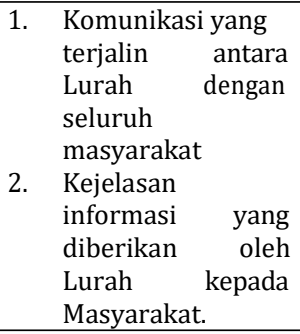 & $\begin{array}{l}46,8 \% \\
45,6 \%\end{array}$ \\
\hline $\begin{array}{l}\text { Teknik } \\
\text { fasilitas }\end{array}$ & $\begin{array}{l}\text { Kesesuaian antara } \\
\text { fasilitas yang } \\
\text { disediakan oleh Lurah } \\
\text { dengan apa yang } \\
\text { menjadi kebutuhan } \\
\text { masyarakat. }\end{array}$ & $45 \%$ \\
\hline $\begin{array}{c}\text { Teknik } \\
\text { motivasi }\end{array}$ & 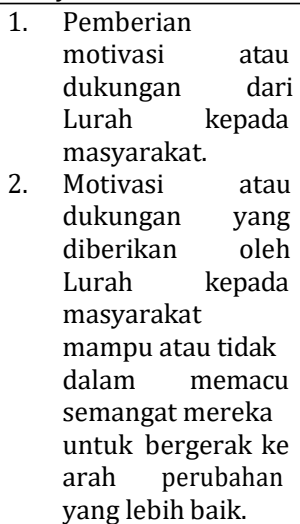 & $\begin{array}{c}45,8 \% \\
44 \%\end{array}$ \\
\hline $\begin{array}{c}\text { Teknik } \\
\text { keteladanan }\end{array}$ & $\begin{array}{l}\text { Lurah mampu atau } \\
\text { tidak untuk menjadi } \\
\text { contoh atau suri } \\
\text { tauladan yang baik bagi } \\
\text { seluruh masyarakat. }\end{array}$ & $42,6 \%$ \\
\hline \multicolumn{2}{|c|}{ Total Rekapitulasi Variabel X } & $45,17 \%$ \\
\hline
\end{tabular}

Sumber: Hasil Olah Data Kuesioner (Mei 2019)

Dengan mengakumulasi hasil rata-rata persentase dari tujuh item pertanyaan pada indikator dari variabel $\mathrm{X}$ di atas, maka diperoleh hasil rata-rata persentase, yaitu $45,17 \%$ atau berada dalam kategori "Cukup Baik".

Berdasarkan tabel 8, ada lima indikator dalam Kepemimpinan Lurah (X) yang dilakukan oleh peneliti untuk mengukur bagaimana
Kepemimpinan Lurah di Kelurahan Lautang Benteng Kecamatan Maritengngae Kabupaten Sidenreng Rappang. Adapun indikator yang pertama adalah teknik persuasif, di mana Lurah berusaha untuk mempengaruhi masyarakatnya agar ikut serta dalam suatu kegiatan dengan membujuk masyarakatnya dengan cara yang baik. Dari hasil persentase didapatkan 46,4\% termasuk dalam kategori cukup baik.

Untuk indikator yang kedua yakni teknik komunikatif ada dua item yang dibahas oleh peneliti. Yang pertama adalah di mana Lurah tetap berusaha untuk menjalin komunikasi dengan seluruh masyarakatnya, memperoleh hasil persentase 46,8\% termasuk dalam kategori cukup baik. Item kedua yaitu penyampaian pesan atau informasi yang jelas dari Lurah kepada masyarakat, memperoleh hasil persentase $45,6 \%$ termasuk dalam kategori cukup baik.

Indikator ketiga adalah teknik fasilitas, Lurah berupaya menyediakan fasilitas atau sarana prasarana yang dapat membantu atau memudahkan segala kegiatan masyarakat, memperoleh hasil persentase $45 \%$ termasuk dalam kategori cukup baik.

Indikator keempat yaknik teknik motivasi juga ada dua item yang dibahas oleh peneliti. Yang pertama adalah pemberian motivasi atau dukungan dari Lurah kepada masyarakat, memperoleh hasil persentase $45,8 \%$ termasuk dalam kategori cukup baik. Item kedua yakni motivasi atau dukungan yang diberikan oleh Lurah kepada masyarakatnya mampu memacu 
semangat mereka untuk bergerak ke arah perubahan yang lebih baik, memperoleh hasil persentase 44\% termasuk dalam kategori cukup baik.

Selanjutnya untuk indikator kelima atau indikator terakhir yaitu teknik keteladanan, di mana Lurah sebagai pemimpin bisa dijadikan panutan atau teladan bagi masyarakat memperoleh hasil persentase $42,6 \%$ termasuk dalam kategori cukup baik. Dari kelima indikator kepemimpinan lurah, indikator yang paling dominan adalah indikator teknik persuasif yakni $46,4 \%$ dan indikator yang paling rendah adalah indikator teknik keteladanan yakni 42,6\%.

Jika dibandingkan dengan penelitian terdahulu, yang dilakukan oleh Arianto, Warjio, dan Tarigan (2016) berdasarkan dengan rekapitulasi delapan indikator yang digunakan termasuk dalam kategori "baik". Indikator yang paling rendah adalah melengkapi fasilitas kerja. Berdasarkan hasil penelitian yang dilakukan oleh Arianto, Warjio, dan Tarigan di Kantor Kelurahan Lubuk Pakam I-II, fasilitas yang tersedia di kelurahan tersebut sudah cukup memadai, walaupun disana sini masih perlu adanya beberapa yang perlu ditambahkan. Lurah Lubuk Pakam I-II selalu berupaya melengkapi fasilitasfasilitas tersebut, walaupun dilakukan secara bertahap. Hal tersebut disebabkan karena keterbatasan dana untuk mencukupi sarana dan prasarana yang lainnya.

Hasil wawancara yang telah dilakukan oleh peneliti pada hari Senin, 21 Mei 2019 pukul 10.20 wita di Kantor Kelurahan Lautang Benteng dengan Bapak Sekretaris Kelurahan Lautang Benteng dan beliau mengatakan bahwa:

"Jika ada sosialisasi atau kegiatankegiatan yang diselenggarakan di Kelurahan Lautang Benteng, yang diberi perintah untuk mengajak masyarakat agar turut hadir atau mengikuti kegiatan tersebut adalah setiap kepala lingkungan. Dalam hal ini, Lurah tidak turun secara langsung untuk memanggil atau mengajak masyarakat".

"Tidak semua masyarakat Kelurahan Lautang Benteng bertatap muka dan berkomunikasi secara langsung dengan Lurah. Biasanya yang berkomunikasi secara langsung adalah masyarakat yang datang untuk meminta pelayanan dari kelurahan, itupun jika Lurah sedang berada di kantor. Adapun mengenai pemberitahuan atau informasi tidak disampaikan secara langsung oleh Lurah, yang menjadi penyalur informasi tersebut adalah ketiga kepala lingkungan atau aparatur pemerintahan kelurahan lainnya".

"Fasilitas atau sarana prasarana yang dapat membantu atau memudahkan segala kegiatan masyarakat memang masih kurang memadai. Bahkan jika ditinjau dari sisi pelayanan, fasilitas-fasilitasnya juga masih minim sehingga kualitas pelayanan yang diberikan jauh dari yang diharapkan oleh masyarakat".

"Kepala Kelurahan tidak memotivasi masyarakat secara langsung, tetapi beliau tetap memikirkan tentang halhal baru yang harus diterapkan dan mudah diterima oleh masyarakat Lautang Benteng tanpa harus 
memotivasi mereka. Beliau ingin memberdayakan setiap potensi yang dimiliki oleh masyarakatnya agar mereka bisa lebih kreatif dan produktif".

"Penilaian setiap masyarakat tentang kinerja hingga kepribadian Lurah pasti berbeda. Jika menurut mereka Lurah memiliki sifat dan perilaku yang patut untuk ditiru atau dicontoh, maka Lurah berhak untuk dijadikan panutan atau teladan oleh masyarakatnya".

\section{2) Pemberdayaan masyarakat}

Dari variabel pemberdayaan masyarakat diperoleh hasil sesuai tabel-tabel indikator dibawah ini.

Tabel 9 Tanggapan responden tentang pelaksanaan kegiatan pelatihan untuk pengembangan kemampuan masyarakat

\begin{tabular}{|c|c|c|c|c|}
\hline $\begin{array}{c}\text { Alternatif } \\
\text { Jawaban }\end{array}$ & Bobot & Frekuensi & Skor & $\begin{array}{c}\text { Persentase } \\
(\%)\end{array}$ \\
\hline $\begin{array}{c}\text { Sangat } \\
\text { baik }\end{array}$ & 5 & 0 & 0 & $0 \%$ \\
\hline Baik & 4 & 4 & 16 & $4,1 \%$ \\
\hline $\begin{array}{c}\text { Cukup } \\
\text { baik }\end{array}$ & 3 & 16 & 48 & $16,7 \%$ \\
\hline $\begin{array}{c}\text { Kurang } \\
\text { baik }\end{array}$ & 2 & 45 & 90 & $46,9 \%$ \\
\hline Tidak baik & 1 & 31 & 31 & $32,3 \%$ \\
\hline \multicolumn{2}{|c|}{ Jumlah } & 96 & 185 & $100 \%$ \\
\hline \multicolumn{2}{|c|}{$185 / 96=1,92$} \\
\hline \multicolumn{2}{c}{$\begin{array}{c}\text { Rata-rata skor } \\
\text { persentase }\end{array}$} & \multicolumn{2}{|c|}{$1,92 / 5 \times 100 \%=38,4 \%$} \\
\hline
\end{tabular}

Sumber: Hasil Olah Data Kuesioner (Mei 2019)
Tabel 10 Tanggapan responden tentang pelaksanaan kegiatan peningkatan pengetahuan masyarakat dalam pengelolaan suatu usaha atau bisnis

\begin{tabular}{|c|c|c|c|c|}
\hline $\begin{array}{c}\text { Alternatif } \\
\text { Jawaban }\end{array}$ & Bobot & Frekuensi & Skor & $\begin{array}{c}\text { Persentase } \\
(\%)\end{array}$ \\
\hline $\begin{array}{c}\text { Sangat } \\
\text { baik }\end{array}$ & 5 & 0 & 0 & $0 \%$ \\
\hline Baik & 4 & 2 & 8 & $2 \%$ \\
\hline $\begin{array}{c}\text { Cukup } \\
\text { baik }\end{array}$ & 3 & 18 & 54 & $18,8 \%$ \\
\hline $\begin{array}{c}\text { Kurang } \\
\text { baik }\end{array}$ & 2 & 55 & 110 & $57,3 \%$ \\
\hline $\begin{array}{c}\text { Tidak baik } \\
\text { Jumlah }\end{array}$ & 21 & 21 & $21,9 \%$ \\
\hline \multicolumn{2}{|c|}{ Rata-rata skor } & 96 & 193 & $100 \%$ \\
\hline $\begin{array}{c}\text { Rata-rata } \\
\text { persentase }\end{array}$ & $2,01 / 5 \times 100 \%=40,2 \%$ \\
\hline
\end{tabular}

Sumber: Hasil Olah Data Kuesioner (Mei 2019)

Tabel 11 Tanggapan responden tentang peningkatan peran serta masyarakat dalam mengelola sumber daya alam yang ada untuk perbaikan lingkungan

\begin{tabular}{|c|c|c|c|c|}
\hline $\begin{array}{c}\text { Alternatif } \\
\text { Jawaban }\end{array}$ & Bobot & Frekuensi & Skor & $\begin{array}{c}\text { Persentase } \\
(\%)\end{array}$ \\
\hline Sangat baik & 5 & 0 & 0 & $0 \%$ \\
\hline Baik & 4 & 3 & 12 & $3,1 \%$ \\
\hline Cukup baik & 3 & 19 & 57 & $19,8 \%$ \\
\hline Kurang baik & 2 & 45 & 90 & $46,9 \%$ \\
\hline Tidak baik & 1 & 29 & 29 & $30,2 \%$ \\
\hline \multicolumn{2}{|c|}{ Jumlah } & 96 & 188 & $100 \%$ \\
\hline Rata-rata skor & \multicolumn{4}{|c|}{$188 / 96=1,95$} \\
\hline Rata-rata persentase & \multicolumn{3}{|c|}{$1,95 / 5 \times 100 \%=39 \%$} \\
\hline
\end{tabular}

Sumber: Hasil Olah Data Kuesioner (Mei 2019)

Tabel 12 Tanggapan responden tentang kepengurusan organisasi kemasyarakatan yang telah terbentuk

\begin{tabular}{|c|c|c|c|c|}
\hline $\begin{array}{c}\text { Alternatif } \\
\text { Jawaban }\end{array}$ & Bobot & Frekuensi & Skor & $\begin{array}{c}\text { Persentase } \\
(\%)\end{array}$ \\
\hline $\begin{array}{c}\text { Sangat } \\
\text { baik }\end{array}$ & 5 & 0 & 0 & $0 \%$ \\
\hline Baik & 4 & 4 & 16 & $4,2 \%$ \\
\hline $\begin{array}{c}\text { Cukup } \\
\text { baik }\end{array}$ & 3 & 23 & 69 & $24 \%$ \\
\hline $\begin{array}{c}\text { Kurang } \\
\text { baik }\end{array}$ & 2 & 56 & 112 & $58,3 \%$ \\
\hline Tidak baik & 1 & 13 & 13 & $13,5 \%$ \\
\hline \multicolumn{2}{|c|}{ Jumlah } & 96 & 210 & $100 \%$ \\
\hline \multicolumn{3}{|c|}{ Rata-rata skor } & \multicolumn{3}{|c|}{$210 / 96=2,18$} \\
\hline Rata-rata persentase & $2,18 / 5 \times 100 \%=43,6 \%$ \\
\hline
\end{tabular}

Sumber: Hasil Olah Data Kuesioner (Mei 2019) 
Tabel 13 Tanggapan responden tentang kemampuan anggota-anggota organisasi kemasyarakatan dalam menjalankan tugasnya

\begin{tabular}{|c|c|c|c|c|}
\hline $\begin{array}{c}\text { Alternatif } \\
\text { Jawaban }\end{array}$ & Bobot & Frekuensi & Skor & $\begin{array}{c}\text { Persentase } \\
(\%)\end{array}$ \\
\hline $\begin{array}{c}\text { Sangat } \\
\text { mampu }\end{array}$ & 5 & 0 & 0 & $0 \%$ \\
\hline Mampu & 4 & 1 & 4 & $1 \%$ \\
\hline $\begin{array}{c}\text { Cukup } \\
\text { mampu }\end{array}$ & 3 & 17 & 51 & $17,7 \%$ \\
\hline $\begin{array}{c}\text { Kurang } \\
\text { mampu }\end{array}$ & 2 & 44 & 88 & $45,8 \%$ \\
\hline $\begin{array}{c}\text { Tidak } \\
\text { mampu }\end{array}$ & 1 & 34 & 34 & $35,4 \%$ \\
\hline \multicolumn{2}{|c|}{ Jumlah } & 96 & 177 & $100 \%$ \\
\hline \multicolumn{2}{|c|}{$177 / 96=1,84$} \\
\hline \multicolumn{2}{|c|}{$\begin{array}{c}\text { Rata-rata skor } \\
\text { persentase }\end{array}$} & \multicolumn{3}{|c|}{$1,84 / 5 \times 100 \%=36,8 \%$} \\
\hline
\end{tabular}

Sumber: Hasil Olah Data Kuesioner (Mei 2019)

Dari hasil yang diperoleh dalam tabel-tabel indikator dari variabel pemberdayaan masyarakat diatas maka rekapitulasi variabelnya dapat dilihat pada Tabel 14 dibawah ini.

Tabel 14 Rekapitulasi Variabel Pemberdayaan Masyarakat (Y)

\begin{tabular}{|c|c|c|}
\hline Indikator & Tanggapan Responden & $\begin{array}{c}\text { Persentas } \\
\text { e (\%) }\end{array}$ \\
\hline Bina manusia & $\begin{array}{lr}\begin{array}{l}\text { Pelaksanaan } \\
\text { pelatihan }\end{array} & \text { kegiatan } \\
\text { pengembangan } & \text { untuk } \\
\text { kemampuan masyarakat. }\end{array}$ & $38,4 \%$ \\
\hline Bina usaha & $\begin{array}{lr}\text { Pelaksanaan } & \text { kegiatan } \\
\text { peningkatan } & \text { pengetahuan } \\
\text { masyarakat } & \text { dalam } \\
\text { pengelolaan } & \text { suatu } \\
\text { atau bisnis. } & \\
\end{array}$ & $40,2 \%$ \\
\hline $\begin{array}{c}\text { Bina } \\
\text { lingkungan }\end{array}$ & $\begin{array}{l}\text { Peningkatan peran serta } \\
\text { masyarakat dalam } \\
\text { mengelola sumber daya } \\
\text { alam yang ada untuk } \\
\text { perbaikan lingkungan. }\end{array}$ & $39 \%$ \\
\hline $\begin{array}{c}\text { Bina } \\
\text { kelembagaan }\end{array}$ & $\begin{array}{l}\text { 1. Kepengurusan } \\
\text { organisasi } \\
\text { kemasyarakatan yang } \\
\text { telah terbentuk. } \\
\text { 2. Kemampuan anggota- } \\
\text { anggota organisasi } \\
\text { kemasyarakatan dalam } \\
\text { menjalankan tugasnya. }\end{array}$ & $36,8 \%$ \\
\hline & Jumlah rata-rata & $40,2 \%$ \\
\hline \multicolumn{2}{|c|}{ Total Rekapitulasi Variabel Y } & $39,6 \%$ \\
\hline
\end{tabular}

Sumber: Hasil Olah Data Kuesioner (Mei 2019)
Dengan mengakumulasi hasil rata-rata persentase dari lima item pertanyaan pada indikator dari variabel $Y$ di atas, maka diperoleh hasil rata-rata persentase, yaitu $39,6 \%$ atau berada dalam kategori "Kurang Baik".

Berdasarkan tabel 14 ada empat indikator dalam Pemberdayaan Masyarakat (Y) yang dilakukan oleh peneliti untuk mengukur bagaimana Pemberdayaan Masyarakat di Kelurahan Lautang Benteng Kecamatan Maritengngae Kabupaten Sidenreng Rappang. Adapun indikator yang pertama adalah bina manusia, yakni pelaksanaan kegiatan pelatihan dan pendidikan untuk pengembangan kemampuan (potensi) masyarakat, memperoleh hasil persentase $38,4 \%$ termasuk dalam kategori kurang baik.

$$
\text { Indikator kedua bina }
$$

kemanusiaan, yakni kegiatan pelatihan atau peningkatan pengetahuan masyarakat untuk mengelola usahanya memperoleh hasil persentase $40,2 \%$ termasuk dalam kategori kurang baik.

Indikator ketiga bina lingkungan ialah peningkatan peran serta masyarakat dalam mengelola sumber daya alam yang ada demi perbaikan lingkungan, memperoleh hasil persentase $39 \%$ termasuk dalam kategori kurang baik.

Indikator keempat atau yang terakhir yaitu bina kelembagaan ada dua item yang dibahas oleh peneliti. Yang pertama adalah kepengurusan kelompok atau organisasi kemasyarakatan yang telah terbentuk, memperoleh hasil persentase $43,6 \%$ termasuk dalam 
kategori cukup baik. Item kedua yakni mengenai kemampuan

kelompok atau organisasi tersebut dalam menjalankan tugas-tugasnya, memperoleh hasil persentase $36,8 \%$ termasuk dalam kategori kurang baik.

Dari keempat indikator pemberdayaan masyarakat, indikator yang paling dominan adalah indikator

bina usaha dan bina kelembagaan yakni $40,2 \%$ dan indikator yang

paling rendah adalah indikator bina manusia yakni 38,4\%.

Jika dibandingkan dengan penelitian terdahulu, yang dilakukan oleh Zulfahri (2016) berdasarkan dengan rekapitulasi enam indikator yang digunakan termasuk dalam kategori "cukup baik". Indikator yang paling rendah adalah melengkapi bekerjasama (collaborating). Berdasarkan hasil penelitian yang dilakukan oleh Zulfahri di Desa Sukamenak Kecamatan Margahayu Kabupaten Bandung, tidak produktifnya karang taruna memiliki keterkaitan erat dengan pemberdayaan masyarakat dalam hal ini pemberdayaan kepada anggota karang taruna Desa Sukamenak yang belum berjalan secara optimal. Salah satu yang menjadi penghambat produktivitas karang taruna adalah terkait dengan masalah kurangnya kerjasama padahal kerjasama tersebut sangat dibutuhkan karena akan menjamin terlaksananya perubahan strategis. Hal itu dikarenakan setiap anggota karang taruna yang masih mengedepankan sikap egois dan emosi dalam berdiskusi serta masih adanya ketergantungan kepada ketua sebagai pemimpin karang taruna dalam memecahkan permasalahan yang terjadi, khususnya terkait dengan masalah dalam organisasi karang taruna itu sendiri.

Adapun hasil wawancara yang telah dilakukan oleh peneliti pada hari Senin, 21 Mei 2019 pukul 10.20 wita di Kantor Kelurahan Lautang Benteng dengan Bapak Sekretaris Kelurahan Lautang Benteng dan beliau mengatakan bahwa:

"Yang diberi tanggung jawab untuk meningkatkan pengetahuan, sikap dan keterampilan masyarakat melalui pendidikan dan pelatihan adalah lembaga organisasi-organisasi yang berperan sebagai mitra pemberdayaan masyarakat. Namun hingga saat ini kegiatan seperti pendidikan dan pelatihan untuk masyarakat belum ada yang dilaksanakan".

"Beberapa masyarakat di Kelurahan Lautang Benteng berinisiatif untuk mengelola suatu usaha kecil-kecilan. Usaha yang dominan digeluti adalah di bidang perdagangan dan industri atau kerajinan. Terkait dengan kegiatan pelatihan atau peningkatan pengetahuan masyarakat untuk mengelola usahanya belum pernah dilaksanakan, karena masyarakat telah mampu untuk mengembangkan usaha mereka dengan mendistribusikan hasil produksinya secara langsung atau dengan melalui media sosial".

"Di Kelurahan Lautang Benteng sumber daya alam yang sangat besar manfaat atau nilainya adalah lahan pertanian. Lahan pertanian yang subur dan potensial tersebut harus dijaga dengan baik agar tetap memberikan manfaat atau 
menguntungkan masyarakat, khususnya kepada masyarakat yang memang bekerja di bidang pertanian".

"Ada beberapa kelompok atau organisasi kemasyarakatan yang telah terbentuk di mana anggotaanggota dari organisasi tersebut dipilih melalui musyawarah. Tetapi ada masyarakat yang menilai bahwa kemampuan mereka ternyata masih kurang dalam hal memberdayakan atau menggerakkan segala potensi yang dimiliki oleh masyarakat".

\section{3) Uji Kualitas Data}

Uji validitas digunakan untuk mengetahui kevalidan atau kesesuaian data dengan menggunakan metode product moment pearson correlation dengan kriteria sebagai berikut a) jika $R$ hitung $>\mathrm{R}$ tabel, maka dinyatakan valid; b) jika $\mathrm{R}$ hitung < R tabel, maka dinyatakan tidak valid

Tabel 15. Uji Validitas Variabel Kepemimpinan Lurah

\begin{tabular}{|c|c|c|c|}
\hline Item & R hitung & R tabel (sig.5\%) & Keterangan \\
\hline Item 1 & 0,530 & 0,200 & Valid \\
\hline Item 2 & 0,637 & 0,200 & Valid \\
\hline Item 3 & 0,663 & 0,200 & Valid \\
\hline Item 4 & 0,664 & 0,200 & Valid \\
\hline Item 5 & 0,664 & 0,200 & Valid \\
\hline Item 6 & 0,659 & 0,200 & Valid \\
\hline Item 7 & 0,680 & 0,200 & Valid \\
\hline
\end{tabular}

Sumber: Hasil Olah Data Kuesioner (Mei 2019)

Tabel 16. Validitas Variabel Pemberdayaan Masyarakat

\begin{tabular}{|c|c|c|c|}
\hline Item & R hitung & R tabel (sig.5\%) & Keterangan \\
\hline Item 1 & 0,736 & 0,200 & Valid \\
\hline Item 2 & 0,712 & 0,200 & Valid \\
\hline Item 3 & 0,767 & 0,200 & Valid \\
\hline Item 4 & 0,744 & 0,200 & Valid \\
\hline Item 5 & 0,748 & 0,200 & Valid \\
Sumber: HasilOdah Data Kuesioner Mei
\end{tabular}
2019)
Dari hasil uji validitas dengan menggunakan aplikasi SPSS di atas menunjukkan bahwa nilai $R$ Correlations Product Moment lebih besar dari $\mathrm{R}$ tabel, maka data yang ditemukan dinyatakan "Valid".

Uji reliabilitas digunakan untuk mengetahui tingkat kekonsistensian angket yang peneliti gunakan untuk memperoleh data dari para responden. Kriteria uji reliabilitas Alpha Cronbach's adalah a) jika Alpha Cronbach's > R tabel, maka dinyatakan Reliabel atau Konsisten;

2) jika Alpha Cronbach's < R tabel, maka dinyatakan tidak Reliabel.

Tabel 17. Uji Reliabilitas Variabel Kepemimpinan Lurah

\begin{tabular}{|c|c|c|c|}
\hline Item & $\begin{array}{c}\text { Alpha } \\
\text { Cronbach's }\end{array}$ & $\begin{array}{c}\text { R tabel } \\
\text { (sig.5\%) }\end{array}$ & Keterangan \\
\hline Item 1 & 0,743 & 0,200 & Reliabel \\
\hline Item 2 & 0,736 & 0,200 & Reliabel \\
\hline Item 3 & 0,728 & 0,200 & Reliabel \\
\hline Item 4 & 0,726 & 0,200 & Reliabel \\
\hline Item 5 & 0,728 & 0,200 & Reliabel \\
\hline Item 6 & 0,730 & 0,200 & Reliabel \\
\hline Item 7 & 0,727 & 0,200 & Reliabel \\
\hline
\end{tabular}

Sumber: Hasil Olah Data Kuesioner (Mei 2019)

Tabel 18. Uji Reliabilitas Variabel

Pemberdayaan Masyarakat

\begin{tabular}{|c|c|c|c|}
\hline Item & $\begin{array}{c}\text { Alpha } \\
\text { Cronbach's }\end{array}$ & $\begin{array}{c}\text { R tabel } \\
\text { (sig.5\%) }\end{array}$ & Keterangan \\
\hline Item 1 & 0,755 & 0,200 & Reliabel \\
\hline Item 2 & 0,764 & 0,200 & Reliabel \\
\hline Item 3 & 0,750 & 0,200 & Reliabel \\
\hline Item 4 & 0,759 & 0,200 & Reliabel \\
\hline Item 5 & 0,756 & 0,200 & Reliabel \\
\hline
\end{tabular}

Sumber: Hasil Olah Data Kuesioner (Mei 2019)

Dari hasil uji reliabilitas di atas menunjukkan bahwa nilai Alpha Cronbach's lebih besar dari $\mathrm{R}$ tabel maka data yang ditemukan dinyatakan "Reliabel atau Konsisten". 
4) Analisis Regresi Linear

\section{Sederhana}

Analisis regresi linear sederhana digunakan untuk mengetahui arah hubungan antara variabel independen (X) dengan variabel dependen (Y) apakah positif atau negatif dan untuk memprediksi nilai dari variabel dependen apabila nilai variabel independen mengalami kenaikan atau penurunan.

Tabel 19. Analisis Tabel Coefficients Coefficients ${ }^{3}$

\begin{tabular}{|c|c|c|c|c|c|c|}
\hline \multirow[b]{2}{*}{ Model } & & \multicolumn{2}{|c|}{ Unstandardized Coefficients } & \multirow{2}{*}{$\begin{array}{c}\text { Standardized } \\
\text { Coefficients }\end{array}$} & \multirow[b]{2}{*}{1} & \multirow[b]{2}{*}{ Sio. } \\
\hline & & $B$ & Sitd Error & & & \\
\hline 1 & (Constant) & $5.40 ?$ & 1.220 & & 4.431 & 000 \\
\hline & Kepemimpinan Lurah & .285 & .075 & .365 & 3.797 & .000 \\
\hline
\end{tabular}

a. Dependent Variable: Pemberdayaan Massyarakat

Berdasarkan tabel 19, hasil dari uji coeffisients pada bagian ini dikemukakan nilai konstanta $(\alpha)=$ 5,407 dan beta $(\beta)=0,285$ serta nilai $\mathrm{t}$ hitung dan tingkat signifikansi $=$ 0,000, maka model regresi yang digunakan dalam penelitian ini untuk mengukur Kepemimpinan Lurah terhadap Pemberdayaan Masyarakat di Kelurahan Lautang Benteng Kecamatan Maritengngae Kabupaten Sidenreng Rappang, dapat dianalisa berdasarkan koefisien-koefisiennya adalah $Y=\alpha+\beta X ; Y=5,407+0,285 X$. Dari fungsi regresi, maka dapat dijelaskan bahwa a) jika variabel Kepemimpinan Lurah (X) berubah, maka Pemberdayaan Masyarakat (Y) juga akan berubah. Tanda positif menunjukkan perubahan yang searah. Apabila Kepemimpinan Lurah meningkat, maka Pemberdayaan Masyarakat juga akan meningkat dengan koefisien regresi sebesar
0,285 dan sebaliknya, jika Kepemimpinan Lurah menurun, maka Pemberdayaan Masyarakat juga akan menurun dengan koefisien sebesar 0,285; b) nilai konstanta sebesar 5,407 menunjukkan bahwa, jika semua variabel konstan maka Kepemimpinan Lurah masih bersifat positif; c) nilai beta 0,285 , diketahui bahwa variabel yang berpengaruh dominan terhadap Kepemimpinan Lurah (X) adalah Pemberdayaan Masyarakat (Y), berdasarkan nilai beta yang besar. Lebih lanjut, $r$ adalah 0,365 ; $r$ square: $0,133 \times 100 \%=$ 13,3\% (pengaruh $\mathrm{X}$ terhadap $\mathrm{Y}$ ). Sisanya $100 \%-13,3 \%=86,7 \%$ (sisanya dipengaruhi oleh faktor yang lain)

Tabel 20. Analisis Tabel Summary

Model Summary

\begin{tabular}{|l|c|r|r|r|}
\hline $\begin{array}{l}\text { Mode } \\
1\end{array}$ & $\mathrm{R}$ & R Square & $\begin{array}{c}\text { Adjusted R } \\
\text { Square }\end{array}$ & $\begin{array}{c}\text { Std. Error of } \\
\text { the Estimate }\end{array}$ \\
\hline 1 & $.365^{5}$ & .133 & .124 & 2.617 \\
\hline
\end{tabular}

Koefisien determinasi digunakan untuk mengetahui pengaruh $\mathrm{X}$ terhadap $\mathrm{Y}$ dalam menerangkan variasi variabel dependen. Berdasarkan tabel model summary, koefisien determinasi berganda $\left(R^{2}\right)$ atau $r$ square $=0,133$ berarti secara bersama-sama 13,3\% perubahan variabel Pemberdayaan Masyarakat (Y) dapat dijelaskan oleh variabel Kepemimpinan Lurah (X), atau dengan kata lain pengaruh variabel bebas terhadap variabel terikat sebesar 13,3\% sedangkan sisanya $86,7 \%$ dipengaruhi oleh variabel lain yang tidak masuk dalam kerangka konsep penelitian ini. 


\section{E. SIMPULAN DAN SARAN}

Beberapa kesimpulan yang dapat ditarik dari penelitian ini adalah sebagai berikut a) dari hasil analisis olah data tabel frekuensi yang dilakukan, dapat disimpulkan berdasarkan tanggapan responden yang menunjukkan bahwa Kepemimpinan Lurah di Kelurahan Lautang Benteng Kecamatan Maritengngae Kabupaten Sidenreng Rappang berada pada kategori "Cukup Baik" dengan rata-rata persentase 45,17\%; b) dari hasil analisis olah data tabel frekuensi yang dilakukan, dapat disimpulkan berdasarkan tanggapan responden yang menunjukkan bahwa Pemberdayaan Masyarakat di Kelurahan Lautang Benteng Kecamatan Maritengngae Kabupaten Sidenreng Rappang berada pada kategori "Kurang Baik" dengan ratarata persentase 39,6\%; c) kepemimpinan lurah berpengaruh terhadap pemberdayaan masyarakat di Kelurahan Lautang Benteng Kecamatan Maritengngae Kabupaten Sidenreng Rappang, hal ini dibuktikan melalui analisis regresi linear sederhana dengan bantuan program SPSS 22.0 for windows, di mana diperoleh output data dari tabel summary $\mathrm{R}^{2}$ sebesar 0,133 atau $13,3 \%$. Hal ini menunjukkan bahwa kepemimpinan lurah memiliki pengaruh $\quad 13,3 \% \quad$ terhadap pemberdayaan masyarakat sedangkan sisanya $\quad 86,7 \%$ dipengaruhi oleh variabel lain yang tidak masuk dalam kerangka konsep penelitian ini.

\section{DAFTAR PUSTAKA}

Ahmad, J. (2015). Metode Penelitian Administrasi Publik Teori dan Aplikasi. Yogyakarta: Gava Media.

BIBLIOGRAPHY Kartono, K. (2014). Pemimpin dan Kepemimpinan. Jakarta: Rajawali Pers.

Damis Dadda, A., Mustanir, A., Nilwana, A., \& Ahmad, J. (2019). Pengaruh Kepemimpinan Lurah Perempuan Terhadap Stabilitas Kamtibmas Di Kelurahan Rappang Kabupaten Sidenreng Rappang. In Konferensi Nasional $\mathrm{Ke}-\mathrm{B} \quad$ Asosiasi Program Pascasarjana Perguruan Tinggi Muhammadiyah Aisyiyah (APPPTMA) (pp. 378-383).

Medan: Program Pascasarjana Universitas Muhammadiyah Yogyakarta. Retrieved from http://asosiasipascaptm.or.id/in dex.php/publikasi/prosidingkonferensi-nasional-appptma-ke8

Irwan, I., Latif, A., Sofyan, S., Mustanir, A., \& Fatimah, F. (2019). Gaya Kepemimpinan, Kinerja Aparatur Sipil Negara dan Partisipasi Masyarakat Terhadap Pembangunan Di Kecamatan Kulo Kabupaten Sidenreng Rappang. MODERAT: Jurnal Ilmiah Ilmu Pemerintahan Universitas Galuh Ciamis, 5(1), 32-43. Retrieved from https://jurnal.unigal.ac.id/index. php/moderat/article/view/1900

Kholifah R, E., \& Mustanir, A. (2019). Food Policy and Its Impact on Local Food. Journal of Asian Review of Public Affairs and Policy (ARPAP), 4(3), 1-15. https://doi.org/http://dx.doi.org /10.222.99/arpap/2019.57

Latif, A., Mustanir, A., \& Irwan, I. (2019). Kepemimpinan Pemerintahan Desa, Partisipasi Masyarakat dan 
Perencanaan Pembangunan.

Rappang: CV. Penerbit Qiara Media.

Mardikanto, T; Soebiato, P. (2017). Pemberdayaan Masyarakat dalam Perspektif Kebijakan Publik. Bandung: Alfabeta.

Mustanir, A., \& Abadi, P. (2017). PARTISIPASI MASYARAKAT

DALAM MUSYAWARAH

RENCANA PEMBANGUNAN DI

KELURAHAN KANYUARA

KECAMATAN WATANG

SIDENRENG KABUPATEN

SIDENRENG RAPPANG. Jurnal

Politik Profetik, 5(2), 247-261.

Retrieved from

http://journal.uin-

alauddin.ac.id/index.php/jpp/art

icle/viewFile/4347/3986

Mustanir, A., \& Darmiah, D. (2016). IMPLEMENTASI KEBIJAKAN

DANA DESA DAN PARTISIPASI MASYARAKAT DALAM

PEMBANGUNAN DI DESA

TETEAJI KECAMATAN TELLU

LIMPOE KABUPATEN

SIDENRENG RAPPANG. Jurnal

Politik Profetik, 4(2), 225-238.

Retrieved from

http://journal.uin-

alauddin.ac.id/index.php/jpp/art icle/view/2749

Mustanir, A., Hamid, H., \& Syarifuddin, R. N. (2019). Pemberdayaan Kelompok Masyarakat Desa Dalam Perencanaan Metode Partisipatif. MODERAT: Jurnal Ilmiah Ilmu Pemerintahan, 5(3), 227-239. Retrieved from https://jurnal.unigal.ac.id/index. php/moderat/article/view/2677

Mustanir, A., \& Jaya, I. (2016). PENGARUH KEPEMIMPINAN DAN BUDAYA POLITIK TERHADAP PERILAKU PEMILIH TOWANI TOLOTANG DI KECAMATAN MARITENGNGAE KABUPATEN SIDENRENG RAPPANG. Jurnal Politik Profetik,
4(1), 84-97. Retrieved from http://journal.uinalauddin.ac.id/index.php/jpp/art icle/view/2741\#

Mustanir, A., \& Lubis, S. (2017). Participatory Rural Appraisal in Deliberations of Development Planning. International Conference On Democracy, Accountability, and Governance (ICODAG 2017) (Vol. 163). https://doi.org/10.2991/icodag17.2017.60

Mustanir, A., Madaling, M., Uceng, A., Kasau, M. N. R., Barisan, B., \& Andriani, D. (2019). Karakteristik Kepemimpinan Lurah Terhadap Partisipasi Masyarakat Dalam Musyawarah Perencanaan Pembangunan Di Kelurahan Duampanua Kecamatan Baranti Kabupaten Sidenreng Rappang. Jurnal Ilmiah Clean Government (JCG), 2(2), 145-172.

Mustanir, A., Ramadhan, M. R., Razak, M. R. R., Lukman, L., Sapri, S., \& Takhrim, T. (2019). Peranan camat dan Komunikasi Pemerintahan Terhadap Perencanaan Pembangunan di Kecamatan Malua Kabupaten Enrekang. Jurnal Ilmiah Clean Government (JCG), 2(2), 94-114.

Sellang, Kamaruddin; Ahmad, Jamaluddin; Mustanir, A. (2019). Strategi dalam peningkatan kualitas pelayanan publik. (Q. Media, Ed.) (1st ed.). Rappang: CV. Penerbit Qiara Media. Retrieved from

https://www.researchgate.net/p ublication/335000572_Strategi_d alam_Peningkatan_Kualitas_Pelay anan_Publik_Dimensi_Konsep_In dikator_dan_Implementasinya?_s $\mathrm{g}=\mathrm{lIz}$ -

IRq6mZhwh1LW1F4FsWj679IsZ XHWNBS6aQjlY0lDOWpb2qAhp NSEDg29L28NxSu6-asTSMDE80eTsfwAb5Q1lCNgOBtmP02m9UA 
.u76ku9orzaS1VzABirs590BoZZi

RGmuHDoF7qAdPMPGugda64e6

8NHN823oS9G_kaeYbBbZYNWqc

Ngtfe0gigQ

Sriekaningsih, A. (2017). Pengaruh Kepemimpinan, Budaya Organisasi dan Lingkungan Kerja serta Kepuasan Kerja terhadap Kinerja Pegawai Wilayah Kecamatan Kota Tarakan. Jurnal Borneo Administrator, 60.

Sugiyono. (2014). Metode Penelitian Kombinasi (Mixed Methods). Bandung: Alfabeta.

Syafiie, I K. (2013). Kepemimpinan Pemerintahan Indonesia. Bandung: Refika Aditama.

Syarifudin, M. (2013). Studi Tentang Kepemimpinan Lurah dalam Meningkatkan Disiplin Kerja Pegawai di Kelurahan Pelita Kota Samarinda. eJournal Ilmu Pemerintahan, 1231.

Theresia, A.; Andini, K. S.; Nugraha, P. G.; dan Mardikanto, T. (2015). Pembangunan Berbasis Masyarakat. Bandung: Alfabeta.

Uceng, A., Ali, A., Mustanir, A., \& Nirmawati, N. (2019). Analisis Tingkat Partisipasi Masyarakat Terhadap Pembangunan Sumber Daya Manusia Di Desa Cemba Kecamatan Enrekang Kabupaten Enrekang. Jurnal MODERAT, 5(2), 1-17. Retrieved from https://jurnal.unigal.ac.id/index. php/moderat/article/view/2125 